\author{
Zikrur Rahmat $^{1 \mathrm{~A}}$, Irfandi $^{\mathrm{A}, \mathrm{B}}$, Abdullah Al-Hazmy ${ }^{\mathbf{B}^{\mathrm{B}}}$ \\ Sapta Kunta Purnama ${ }^{B}$, Agus Kristiyanto ${ }^{B}$

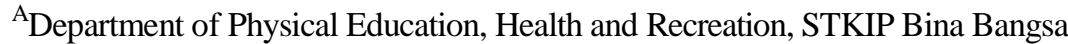 \\ Getsempena, Aceh, Indonesia \\ ${ }^{\mathrm{B}}$ Department of Sports Science, Universitas Sebelas Maret, Surakarta, Indonesia

\section{Evaluation of athletic club training management fostered by youth and sports department, Aceh Province, Indonesia ${ }^{3}$}

\begin{abstract}
This study aims to evaluate the management of the athletic club, especially jump and throwing numbers under Youth and Sports Department of Aceh, and specifically aimed to assess the extent to which the development of the management of athletic sports clubs in each district/sub- district under the Youth and Sports Department of Aceh. This research is conducted in Sabang, Aceh Besar, Pidie Jaya, Bener Meriah, Gayo Lues, Aceh Jaya, Simeulue and Aceh Singkil. The method used is a qualitative research method, where only judging, see the feasibility of development management of athletic club management. The result of the research and discussion shows that the management process of an athletic club in Aceh is still minimal, this is because the management, recruitment process, and financing are still classified as less, still in the stage of revamping towards the more advanced.
\end{abstract}

Keywords: athletic, evaluation, management

\title{
Introduction
}

The role of a coaching management is very important in carrying out any training activities, so as to achieve higher achievement. Achievements in athletics if the trainer in carrying out the training can manage and cultivate it well [1]. Factors that influence the achievement of one of them are factors related to management by the trainer in addition to other factors such as the organizing factor of the match, profiles of the

\footnotetext{
${ }^{1}$ Zikrur Rahmat, e-mail: zikrur@stkipgetsempena.ac.id

${ }^{2}$ Abdullah Al-Hazmy, e-mail: alhazmy99@gmail.com

${ }^{3}$ Przedruk z: Rahmat Zikrur, Irfandi, Al-Hazmy Abdullah, Purnama Sapta Kunta, Kristiyanto Agus. Evaluation of athletic club training management fostered by youth and sports department, Aceh province, Indonesia. Journal of Education, Health and Sport. 2018;8(10):62-76.
} 
condition of athletes and nutritional factors, funds, infrastructure facilities and motivation from other people [2].

Therefore, knowledge is not enough to achieve a higher level of achievement [3]. The achievements of an athlete or team are only achieved if the coach really masters all the intricacies of his coaching[1]. The high and low performance of athletes is very dependent on the high and low knowledge and skills of the coach. Thus the trainer will be able to manage the entire training process so that the expected achievement will be maximized [4].

The branch of athletic sports is the most popular sport in the community, both domestic and foreign. This branch of fostered athletic sports in the Youth and Sports Department of Aceh has reaped a lot of achievements both at the regional and national levels, but recently the athletic sport has rarely been heard as a champion at the national level, they are only able to defend at the regional levels. What's wrong with the Athletics Sports? then to answer the challenge. On this occasion, researchers were interested in conducting research on management, especially the management of training for the athletic sports club of the Youth and Sports Department of Aceh Province.

The term management has many meanings, depending on the person who interpreted it. The term management is often compared to administrative terms. In this regard, there are three different views: first, to interpret the broader administration of management; second, see broader management of administration; third, the view that management is identical with the administration [5].

Management is a function to achieve a goal through the activities of others and oversee individual efforts to achieve a common goal, while according to the Encyclopedia of the Social Science states management is a process by which an implementation of a particular goal is organized and supervised [6].

Management tasks are fundamentally oriented towards the task and planning, organizing, coordinating and controlling. A good manager/trainer will need the above activities, in addition to the ability to do work and make the right decisions in order to achieve the goals of the organization $[3,5]$.

\section{Methodology}

The research approach uses qualitative research. This type of qualitative research is a type of research that uses natural settings, with a view to interpreting a phenomenon that occurs and is carried out by means of a variety of methods. The research location includes all Youth and Sports Department Offices in Aceh Province. The location was taken with the consideration that in each City Regency is a representative of each Youth and Sports Department in Aceh to foster, manage athletes, especially the athletics branch.

Data analysis. In this study, researchers used qualitative analysis techniques, namely by remembering a number of data that has been collected mostly are qualitative data. The qualitative analysis model used is by examining the evaluative values of the Youth and Sports Department office in each Regency and the trainers, the athletes who are the object of research are then projected on the policy and the 
feasibility of collaborative evaluation of management between academics, trainers, Youth, and Sports Department, and also the athletes who apply the ideal that is expected, then interpreted based on theory to then be drawn generalization as an ideal formulation.

\section{Result}

From the results of research data collection in several areas including 1) Sabang City, 2) Aceh Besar, 3) Aceh Jaya, 4) Simeulue, 5) Gayo Lues, 6) Pidie Jaya, 7) Aceh Singkil, and 8) Bener Meriah, then in this case can interpret the data that has been done about the design of management evaluations of the management training of Youth and Sports Department Athletic Sports Club in Aceh Province including all Youth and Sports Department in each City District that overshadow athletic sports activities. The feasibility analysis process for the design of management evaluations of the training management of the Youth and Sports Department Athletic- Fostered sports club in Aceh Province including all the Youth and Sports Department in each City that overshadows to foster Athletic sports activities, it can be concluded that the management evaluation design process has gone well, smoothly, well in terms of fund disbursement, infrastructure distribution, achievement at each event organized by Indonesian National Sports Committee, and Indonesia's Ministry of Youth And Sports, it is very proud, this is as evidenced by achievement and medal achievements at the athletic sports club in each regency/city.

Meanwhile, the results of the research obtained through observation, interviews and study documentation of management analysis on the development of athletic athletes fostered by Aceh Youth and Sports Department, then entered the stage of observation activities carried out in three categories, namely places, actors and activities. The interview was conducted on the general in charge of PPLP Aceh, namely Mr. Musri Idris, SE, M.Si as the head of the Youth and Sports Department of Aceh as the person in charge of the Athletics Education and Development Center, Head of the Regional Technical Implementation Unit (UPTD), Mr. Fauzi, SE, as the chief executive of Student Training and Education Activities (PPLP) Aceh, Chairperson of Athletic Coaching Development for Aceh Athletes, Azwar, SH, as daily organizer of Athletics Education and Development activities, Athletics Coach of Aceh Azhari, S.Pd as athletic head coach number jump and run, Nasrullah, S.Pd as coach of throwing number, Hasrizal as coach of number reject and throw, athletes, and parties responsible and directly related to Youth and Sports Department Patronage in Aceh Province.

\section{Observation results}

The results of the observations carried out are the results taken based on direct data obtained from the field. Here's the description; Information from the results of the observation data that is done is the place in the form of a good condition building, 
athletes and coaches can carry out activities comfortably. The meeting room is available and is very adequate and very comfortable for a meeting to run.

The first actor category is that office / secretarial activities exist and run well. Administrative staff exist and carry out their duties according to the responsibilities assigned to them. The trainer room is temporarily using the IPOA office. Data storage is using the office and IPOA facilities because there is no own office specifically for the office of the coach of the Athletics of the Aceh Youth and Sports Department. Activity category, there is a trainer administration stored in the Youth and Sports Department base, a sports equipment warehouse is available but not properly organized. Athletes' dormitories are there and in good condition, athletes are comfortable staying in dormitories. The dining room of athletes is good and clean and worthy of being a healthy and comfortable dining room.

\section{Interview result}

The results of the research were obtained from the results of interviews conducted in accordance with the management function itself which includes planning, organizing, mobilizing and supervising. Based on the results of the research obtained the following data:

1. Results of an interview with Mr. Musri Idris, SE, M.Si as the head of the sports field of Youth and Sports Department Aceh, the person in charge of the Athletics Athletes Education and Development Center.

Vision and mission of Fostered Athletic Athletes in Aceh Youth and Sports Department so that sports can be achieved with great achievements, the mission of advancing sports through sports training, designing fitter humans, sport for all. The goals and objectives are carried out by athletics from the Athletics and Athletes Education and Development Center for the Aceh Youth and Sports Department, which is to promote and ensure sports in Aceh and to cultivate sports in Aceh and to cultivate sports for the purpose of good achievement. The planning that must be carried out in the future of Athletic Athlete Development is how to prepare a work program and good planning in all respects in accordance with management principles namely planning, organizing, staffing, controlling and actuating. The strategic plan also needs to be made for Athletic Athletes Fostered by the Aceh Youth and Sports Department by placing the right people in the right and appropriate positions, encouraging staff to work according to their respective functions and preparing a clear leadership structure. Athletic Athletes Fostered by Aceh Youth and Sports Department towards sports through regulation quality trainers. Operational plans such as funding problems and infrastructures need to be made because the funding factor is very seat so these factors are very important supporting factors for the sustainability of the Aceh Youth and Sports Department Athletic Assisted Athlete program, the concrete operational plan in the form of provided facilities for daily operational costs for athletes and also the dormitory.

The training program and the administrative structure run very well. The indication is that the trainer has implemented the program he made, this is reflected 
in the existence of test parameters in the form of general physical, special and mental ability tests. Short-term and long-term programs prepared by the trainer after a meeting was held with the person in charge of the program. Training schedule for Fostered Athletic Athletes The Aceh Youth and Sports Department is the full authority of the trainer after previously consulting with the person in charge of the Athletic Training Program of the Aceh Youth and Sports Department. The dormitory is also provided for athletes and conditions are still good. Coaching programs are also made, the indications are that they have carried out the programs that have been charged to them, guidebooks / brochures as a reference for implementing tasks to carry out tasks well made, preparation of training supporting facilities in the form of sports equipment is provided, as a result of the operational needs of the exercise activities and the daily life of the athlete, for example providing all the needs needed by athletes. The source of funds for activities carried out by Athletic Athletes Fostered by the Aceh Youth and Sports Department is the National Budget. The funds provided are not enough for the costs or operational needs of the program (a classic problem is the lack of funds). Those involved in the activity are all levels of Youth and Sports Department in accordance with the positions and tasks that have been charged by the government. In preparing all the needs for these activities are obstacles faced, one of which is the low desire of athletes to develop, lack of responsibility of a coach, a little championship, still limited facilities and infrastructure, as well as management weaknesses. The solution to overcoming this is to grow athletes' interests and talents through nurseries so that the availability of athletes with large numbers.

\section{Results of interviews with Fauzi Ibrahim, SE as chairperson of the activities of Athletic Athletes Fostered by Aceh Youth and Sports Department.}

The aim of the Athletic Athletes Fostered by the Aceh Youth and Sports Department is to implement government programs in accordance with the funds allocated by the APBN, to foster high school and college athletes. The planning that must be prepared is program planning referring to the programs that have been prepared by the Menpora and in its implementation, it is not permissible to exit the program set by the Menpora. There is no coaching program at the city level, but talented athletes in the regency/city will be recruited to become athletes in the Athletic Athletes Fostered by the Aceh Youth and Sports Department. Determination of dormitory accommodation is UPTD and in its implementation will be assisted by the dormitory, PKD manager. There are also health workers involved and collaborate with the Crescent Hospital. The source of funds is from the state budget, the funds are sufficient and sufficient for the implementation of the activities of the athletes trained by the Aceh Youth and Sports Department and if there is an addition of athletes the funds will be added, after being legalized by the Menpora. Constraints faced are the transportation of athletes in daily activities. During the Athlete Athletes Coaching Program, there is no achievement at the national level that has been achieved, in this case, the Youth and Sports Department will design in such a way that the birth of athletes who excel at national and international levels for their senior substitutes. The monitoring team in the activities of the coaches of the Athletics Guided by the Aceh Youth and Sports Department also existed, namely the Head of the Sports Department directly dropped off the field as a monitoring team. Every result of the activity is evaluated, if there is a problem with the athlete's performance, the athlete will be 
replaced as well as the coach. In planning there were no obstacles, all went well as long as funds from the APBN supported.

\section{Results of interviews with Azwar, SE, Kasi sports achievements}

Supporting facilities for training activities are adequate, to make this program run properly. What determines the dormitory lodging place is that the Youth and Sports Department party through the UPTD in the implementation will be assisted by the dormitory, manager, and PKD. Health workers are also involved and collaborate with the Crescent Hospital. Sources of funds for activities are APBN. The funds are sufficient, for the implementation of the activities of the Aceh Athletes of the Youth and Sports Department, it is sufficient, at least to keep this program going. The constraints faced are the mentality of the athletes who are still not good. Another obstacle faced is planning, namely athlete recruitment and lack of funding sources for athletes.

\section{Results of interview with Azhari, S.Pd as coach of Athletic Athletes Fostered by Aceh Youth and Sports Department}

The target of each athlete coaching is that the trainer makes a target according to what event will be done and that the Athletes of the Aceh Youth and Sports Department have their own championships. The trainer has a target, the target is to be the best in each event that will be followed, currently, the coach is focusing on getting the best results, in the POPNAS, POMNAS, POPDA and other events. Before carrying out the training, there must be and must be prepared an exercise program to be a guide and reference for the trainer in training, which ultimately leads to athletes who excel. Training schedules are made as guidelines for coaches and athletes to realize their respective responsibilities. and infrastructure of training trainers is inadequate or incomplete due to lack of costs allocated by the government. Training schedules are made as guidelines for trainers and athletes to realize their respective responsibilities. Training infrastructure and facilities are inadequate or incomplete due to costs, allocated. in training, Juda is provided as a guide for training so as not to get out of the rules set by the Youth and Sports Department.

The location to conduct training activities was also provided with the facilities and infrastructure of the Harapan Bangsa Lhong Raya stadium. There is no transportation for trainers, but transportation is provided in the form of transport money. All athletes are altogether submissions from the District sometimes coaches themselves down to pick up talented athletes. Evaluations are also carried out every training carried out with the athlete every time he has finished training or training to improve his movements. itself as an ingredient to monitor the progress of the athlete during training. When training there was a field monitoring team, namely the sports Head departments came alone to monitor the exercise program.

Constraints in training fostered Athletic Athletes in Aceh Youth and Sports Department are, one of them is facilities and infrastructure, training schedules that have not been fully implemented due to various reasons, namely athletes who are formed with the school schedule. this is a success. The achievements that have been achieved by the trainer during training of Athletic Athletes Fostered by Aceh Youth and Sports Department to Vietnam Seagates Laos and Palembang. Regarding the salary of the trainer, he admitted that the salary was relatively smooth. In addition to 
relatively smooth salaries, the welfare of the trainer gets the attention of the relevant Department/management, this can be seen from the indication that the salary is relatively smooth. The aspirations of the athlete are often conveyed to the coach, this is done so that the trainer knows what the obstacles and problems that befall the athlete so that the trainer can find a solution so that the problems do not disrupt their performance both during training and competition. The atmosphere of the training was conducive, there was intimacy between the athlete's coaches and the people involved in the program. The day of documentation retrieval is a day when athletes are doing running exercises to increase speed. The trainer always reviews and monitors every activity that takes place in the field.

\section{Discussion}

Based on the results of research and analysis of data collected from observation, interviews, documentation and observation studies it can be seen that the management of Patronized Athletes in Aceh Youth and Sports Department has carried out the management process in accordance with its functions although there are still deficiencies and constraints faced, this can be seen in the activities the organization has carried out the management of an organization, among others by the existence of a good management arrangement in the form of planning, organizing, mobilizing and supervising from the parties involved in the assistance of the Aceh Athletes. Management and administration do not run their own activities which are organizational in nature but together are in one motion and step [7]. In the administrative process, functions are more general and valid for the whole organization. Whereas the management process functions are more departmental or sectoral $[5,8]$.

Based on the study it can be explained that management and administration do not carry out their own activities which are comprehensive and organizational, but together are in one motion and step[9]. In carrying out coaching activities for the fostered Athletic Athletes the Aceh Youth and Sports Department have carried out the management function well with the planning and targets to be obtained, but there are still obstacles [9-10].

Based on the data collected, it appears that in the process of organizing, there is a fairly maximum coaching activity in accordance with the duties and functions in the management, although there are many obstacles in it, it still needs improvement so that the organization can be carried out optimally [11-12]. In the mobilization process still needs improvement especially in moving members towards the work program, so that later members can follow the program to the fullest. From the data collected, it also appears that weaknesses occur in the process of supervision of specific financial activities. With the management process that has been implemented, it needs to be improved so that it is expected to be a capital in improving sports performance at the national level so that it can lead to peak achievements in accordance with community expectations [13]. 


\section{Conclusion}

From the results of research data collection in several areas including 1) Sabang City, 2) Aceh Besar, 3) Aceh Jaya, 4) Simeulue, 5) Gayo Lues, 6) Pidie Jaya, 7) Aceh Singkil, and 8) Bener Meriah, then in this case can interpret the data that has been done about the design of management evaluations of the management training of Youth and Sports Department Athletic Sports Club in Aceh Province including all Youth and Sports Department in each City District that overshadow athletic sports activities. The feasibility analysis process for the design of management evaluations of the training management of the Youth and Sports Department Athletic-Fostered sports club in Aceh Province including all the Youth and Sports Department in each City Regency that overshadow to foster Athletic sports activities, it can be concluded that the management evaluation design process has gone well, smoothly, well in terms of fund disbursement, infrastructure distribution, achievement at each event organized by Indonesian National Sports Committee, and Indonesia's Ministry of Youth And Sports, it is very proud, this is as evidenced by achievement and medal achievements at the Youth and Sports Department-trained athletic sports club in each regency/city.

\section{Acknowledgment}

We are grateful to 1) the Aceh Youth and Sports Department, 2) the representatives of the Youth and Sports Department in each regency/city, 3) the many contributing research teams, 4) Athletics in each regency/city, 5) athletic trainers under the supervision of Youth and Sports Department of Aceh, which provides an opportunity and place that is very helpful for the research process.

\section{References}

1. Ray R. (2005). Management Strategies in Athletic Training. 3rd ed. Champaign, Ill: Human Kinetics.

2. Weidner TG, Laurent T. (2001). Selection and evaluation guidelines for clinical education settings in athletic training. J Athl Train. 2001;36(1): 62-67.

3. Light, R., \& Dixon, M.A. (2007). Contemporary developments in sport pedagogy and their implications for sport management education. Sport Management Review, 10, 159-175. doi:10.1016/S1441-3523(07)70009-8.

4. Harsuki. (2003). Perkembangan Olahraga Terkini. PT. Raja Grafindo Persada. Jakarta.

5. Adair, J. (2006). Leadership and motivation. London: Kogan Page Ltd.

6. Dirjen Olahraga dan Pemuda. (1973). Dokumen tentang Profesional Olahraga Indonesia. Jakarta. Depdikbud.

7. Swann E. (2005). Nova Southeastern University Athletic Training Student Guidebook. 3rd ed. Fort Lauderdale, Fla: Nova Southeastern University. 
8. Haiman et. al. (2002). Aspek Psikologi dan Pencapaian Prestasi Atlet Nasional, Anima Indonesia An Psychology Journal. Universitas Gajah Mada Press. Yogjakarta.

9. Bompa, Ph.D., Tudor O. (1994).Theory And Methodology Of training. Department of Physical Education. York University in Toronto, Ontario. Canada.

10. Amis, J., Slack, T., \& Hinings, C.R. (2004). Strategic change and the role of interests, power, and organizational capacity. Journal of Sport Management, 18(2), 158-198.

11. Jackowski, M., \& Guillon, L. (1998). Teaching sport management through service learning: An undergraduate case study. Quest, 50, 251-265. doi:10.1080/00336297.1998.10484284

12. Jones, D.F., Brooks, D.D., \& Mak, J.Y. (2008). Examining sport management programs in the United States. Sport Management Review, 11, 77-91. doi:10.1016/S1441-3523(08)70104-9

13. North American Society for Sport Management. (2011). Sport Management Education Journal. Retrieved http://www. nassm.com/InfoAbout/SMEJ 